\title{
Detecting the translocation of DNA through a nanopore using graphene nanoribbons
}

\author{
F. Traversi ${ }^{1}$, C.Raillon ${ }^{1}$, S. M. Benameur ${ }^{2}$, K.Liu ${ }^{1}$, S. Khlybov ${ }^{1}$, M. Tosun ${ }^{2}$, D. Krasnozhon ${ }^{2}$, \\ A.Kis ${ }^{2}$ and A.Radenovic ${ }^{1}$
}

\section{Measurement of the membrane capacitance}

The membrane capacitance $C_{m}$ was experimentally measured by means of AC measurements. When the graphene transistor is disconnected, the impedance seen by the Axopatch Amplifier to ground is approximately (see Fig.5 and Fig SI-7):

$$
R_{p}(j \omega)=\frac{1+j \omega R_{e l} C_{m}}{1+j \omega R_{p} C_{m}} R_{p}
$$

where $\mathrm{R}_{\mathrm{el}}$ is the resistance of the electrolyte, $C_{m}$ is the capacitance associated to the $\mathrm{SiN}_{\mathrm{x}}$ membrane (to be determinate) and $R_{p}$ is the resistance of the pore as measured in DC regime. This expression is valid under the commonly assumed condition $R_{\mathrm{el}}<<\mathrm{R}_{\mathrm{p}}$. At low frequency, namely from the DC regime up to the pole of the transfer function, at a frequency $f_{P}=\frac{1}{2 \pi R_{p} C_{m}}$, the impedance measured by the Axopatch Amplifier is:

$$
R_{p}(0) \cong R_{p}
$$

while for frequencies higher than the zero of the transfer function, placed at $f_{Z}=\frac{1}{2 \pi R_{e l} C_{m}}$, the impedance approaches the value of the resistance of the electrolyte:

$$
R_{p}(j \omega) \cong R_{e l}
$$

Between $f_{P}$ and $f_{Z}$, the impedance $R_{p}(j \omega)$ inversely decreases with the increasing frequency, while the product of the modulus of the impedance and the frequency is constant and equal to the inverse of $C_{m}$ : 


$$
\left|R_{p}(j \omega)\right| \cdot 2 \pi f \cong \frac{1}{C_{m}}
$$

A SR830 DSP lock-in amplifier was used to perform measurements in AC regime. The sin output of the lock-in amplifier was connected to the external control on the back of the Axopatch amplifier, while the scaled output of the Axopatch amplifier was connected to the input of the lock-in. A frequency sweep from $10 \mathrm{~Hz}$ to $10 \mathrm{kHz}$ was performed, sampling on 100 points logarithmically spaced in frequency and excitation amplitude of $4 \mathrm{mV}$ Fig. SI-9 shows the AC measurement performed on a typical device, as it is possible to see, the amplitude of the pore current increases up to a frequency of about $5 \mathrm{kHz}$. Obviously, here we have an increasing behaviour, because the current $I p$ is proportional to the inverse of the impedance:

$$
\widetilde{I_{p}}=\frac{1}{10} \frac{\widetilde{V_{a}}}{\left|R_{p}(j \omega)\right|}
$$

where $\widetilde{V}_{a}=4 \mathrm{mV}$ is the amplitude of the excitation voltage and the factor $\frac{1}{10}$ is the scaling factor at the external control of the Axopatch amplifier. The pole of the transfer function is evidently at a frequency lower than $10 \mathrm{~Hz}$. We can thus write:

$$
\frac{1}{10} \frac{\widetilde{V_{a}}}{\widetilde{I_{p}}} \cdot 2 \pi f \cong \frac{1}{C_{m}}
$$

With reference to Fig. SI-9 the value of $C_{m}$ can then be extrapolated from any point between 10 $\mathrm{Hz}$ and $5 \mathrm{kH}$ with the formula:

$$
C_{m}=10 \frac{\widetilde{I_{p}} / \widetilde{V_{a}}}{2 \pi f}
$$

Taking for example $f=100 \mathrm{~Hz}$ and $\widetilde{I_{p}}=0.452 \mathrm{nA}$, with $\widetilde{V_{a}}=4 \mathrm{mV}$, we compute $C_{m}=1.8 \mathrm{nF}$, that is the value used in the simulation for the $10 \mathrm{mM} \mathrm{KCl}$ conditions. 


\section{ADS Simulations -Cross-talk analysis}

Graphene circuit -transistor, is simplified and represented by the two blocks; one related to the alumina oxide with associated resistance and capacitance and one to the graphene block with associated resistance. Current pulse generators, introduced 1-1.5 ms long events in both channels respectively. In addition for both channels we introduced appropriate levels of Poisson noise using current noise generators. The values of the various lumped elements governing the model for both ionic strength of electrolyte are listed in SI Table 1. Standard DC current voltage characteristics were used to determine nanopore, electrolyte, graphene and oxide resistance, while nanopore capacitance was measured from the nanopore frequency response as already reported by Dimitrov et.al. ${ }^{1}$ and detailed in the previous section of this supporting information. Oxide capacitance and resistance were measured on the membrane having the graphene nanorribon device but lacking the nanopore as shown on the Fig SI 6.

We simulated signals with sampling frequency of $100 \mathrm{kHz}$ for both ionic strengths. As shown in Fig-SI- 8 there is no transmitted signal between two circuits for the high values of the oxide resistance, however if this resistance is reduced 1000 times we start to observe signal crosstalk. Another critical parameter of the model is nanopore capacitance (membrane capacitance). If it is larger than $10 \mathrm{nF}$, we observe significant crosstalk of graphene channel in the ionic but not vice versa. Reducing the membrane/pore capacitance would improve both the frequency and noise performance of the current device. In this prof of principle circuit, the membrane capacitance is actually lumped together with various parasitic elements associated with the double layer -interface between charged surface and electrolyte. 


\section{Properties of working devices}

A total of 22 working devices were fabricated and used for experiments with DNA. The device microfabrication had a yield of approximately $70 \%$. A fraction of the samples were lost mainly because of membrane cracking or over-etching of the graphene constriction resulting in a nonconductive constriction. The key part of the device production is drilling; the yield at this step is around $25 \%$. Most of the devices are very highly conductive or not conductive at all after TEM drilling. Only drilled constrictions with resistances after drilling lower than $500 \mathrm{k} \Omega$ were used for experiments.

\section{Finite Element method -Simulations}

We solved the Poisson-Nernst-Planck equations for the electric potential $\mathrm{V}$ and the $\mathrm{K}^{+} / \mathrm{Cl}^{-}$ion concentration $\mathrm{c}_{ \pm}$using finite-element method (COMSOL Multiphysics 4.2) as proposed by Lee et al. ${ }^{2}$. The corresponding equations coupling the electric potential $\mathrm{V}$ to the ion concentrations $\mathrm{c}_{ \pm}$write

- Poisson equation

$$
\vec{\nabla} \cdot\left(-\varepsilon_{0} \varepsilon \vec{\nabla} V\right)=e N_{a}\left(c_{+}-c_{-}\right)
$$

\section{Nernst-Planck equation}

$$
\begin{aligned}
& \vec{\nabla} \cdot N_{ \pm}=0 \\
& N_{ \pm}=-\mu_{ \pm} k_{B} T \vec{\nabla} c_{ \pm} \mp e \mu_{ \pm} c_{ \pm} \vec{\nabla} V
\end{aligned}
$$

where $\varepsilon$ is the water permittivity, $e$ the elementary charge, $N_{ \pm}$are the $\mathrm{K}^{+} / \mathrm{Cl}^{-}$fluxes, $\mu$ the ion mobility (assumed to be equal for $\mathrm{K}^{+}$and $\mathrm{Cl}^{-}$). 
In all simulations we considered a pore of diameter $D$ and length $L$ using a 2D axisymmetric geometry presented in the Figure below. The pore diameter in the simulation was $10 \mathrm{~nm}$ and the membrane thickness $20 \mathrm{~nm}$, close to the typical experimental geometry shown in the ms (Figures 1, 3 and 4 and SI Figure 3 and 4). Dimensions of the pores for all functional fabricated devices are presented in Table 2.

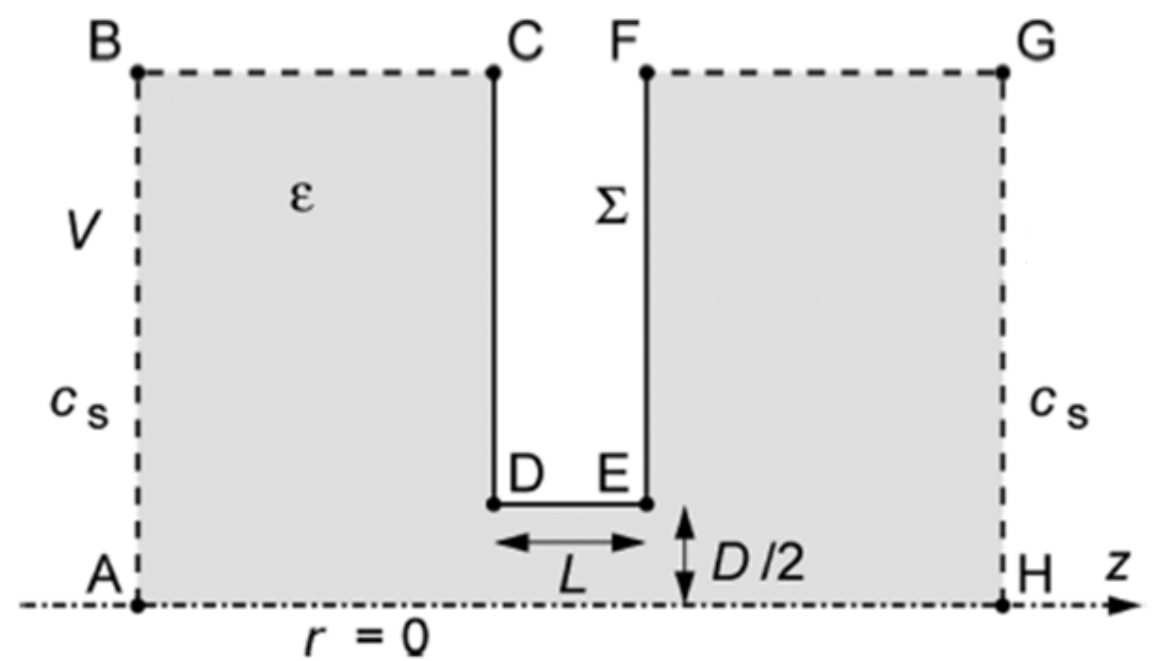

Axisymmetric geometry of the nanopore with length $L$ and diameter $D$ used for the numerical resolution of the corresponding Poisson and Nernst-Planck equations using a finite-element solver (COMSOL). (CDEF) represents the membrane boundaries; the electric potential drop is imposed between equipotentials (AB) and (GH). Taken from ref ${ }_{2}$.

We imposed the following boundary conditions

1. C-D-E-F - The membrane carried a surface charge $\Sigma$, and was impermeable to ions

$$
\vec{n} \cdot\left(-\varepsilon_{0} \varepsilon \vec{\nabla} V\right)=\sum, \vec{n} \cdot \vec{N}_{ \pm}=0
$$

2. B-C, F-G - Far from the pore in the radial direction we imposed a symmetry condition

$$
\vec{n} \cdot\left(-\varepsilon_{0} \varepsilon \vec{\nabla} V\right)=0, \quad \vec{n} \cdot \vec{N}_{ \pm}=0
$$


3. A-B, G-H - We required that both ion concentrations relaxed toward the bulk salt concentration far from the pore in the axial direction, and we imposed a potential difference between the two reservoirs

In order to limit finite size effects, we imposed that the size of the reservoirs was much larger than the pore diameter, the Debye $\left(\lambda_{D}\right)$, and the Dukhin length $\left(l_{D u}\right)$. We also took care that the mesh size was smaller than the Debye length.

$$
l_{D u}=\frac{\kappa_{s}}{\kappa_{b}} \approx \frac{|\Sigma|}{2 e N_{a} c}, \lambda_{D}=\sqrt{\frac{\varepsilon \varepsilon_{0} k_{B} T}{2 e^{2} N_{a} c}},
$$

where $\boldsymbol{\kappa}_{s}$ is the surface conductivity, $\boldsymbol{\kappa}_{\boldsymbol{b}}$ is the bulk conductivity.

Translocating DNA is represented by a 2.2-nm diameter cylinder coaxial as already reported by van Drop et al. ${ }^{3}$ where DNA has a bare line charge density of 2 electrons per base pair. Our simulations are performed for the pores with surface charge set to $+50 \mathrm{mC} / \mathrm{m}^{2}$. To facilitate the simulations in $2 \mathrm{D}$, and we performed simulations one $50 \mathrm{~nm}$ one long linear dsDNA segment translocating the pore.

Since we work with very thin $\operatorname{SiN}_{\mathrm{x}}$ membranes (thickness $\sim 20 \mathrm{~nm}$ ) and the electric field strength inside the nanopore reaches $10^{6} \mathrm{~V} / \mathrm{m}$, we can still assume that the segment of the dsDNA plasmid having persistence length $50 \mathrm{~nm}$ translocates the pore in the fully extended form. Therefore we can assume that the plasmid DNA in the nanopore configuration can be approximated with 2 dsDNA strands that are at least in the pore region locally underwound. To also investigate the possibility that DNA is trapped at the orifice of the of the pore, as recently proposed by Valassarev and Golovcenko, ${ }^{4}$ we placed a DNA torus $9 \mathrm{~nm}$ inside the pore and estimated the change in potential caused by such a trapped DNA configuration can cause. We 
modeled trapped DNA as a ring torus with the 2.5-nm molecular diameter. In all simulations we neglected the DNA - nanopore wall interaction.

\section{References}

1 Dimitrov, V. et al. Nanopores in solid-state membranes engineered for single molecule detection. Nanotechnology 21, doi:Artn 065502 Doi 10.1088/0957-4484/21/6/065502 (2010).

2 Lee, C. et al. Large apparent electric size of solid-state nanopores due to spatially extended surface conduction. Nano Lett 12, 4037-4044, doi:10.1021/nl301412b (2012).

3 van Dorp, S., Keyser, U. F., Dekker, N. H., Dekker, C. \& Lemay, S. G. Origin of the electrophoretic force on DNA in solid-state nanopores. Nat Phys 5, 347-351, doi:Doi 10.1038/Nphys1230 (2009).

4 Vlassarev, D. M. \& Golovchenko, J. A. Trapping DNA near a solid-state nanopore. Biophys J 103, 352-356, doi:10.1016/j.bpj.2012.06.008 (2012). 


\section{SI FIGURES}

\section{SI-FIGURE 1}

a)

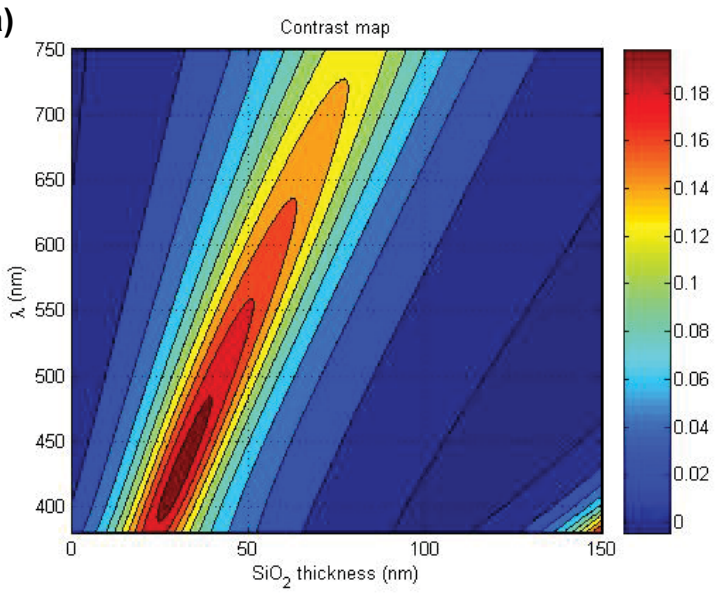

b)

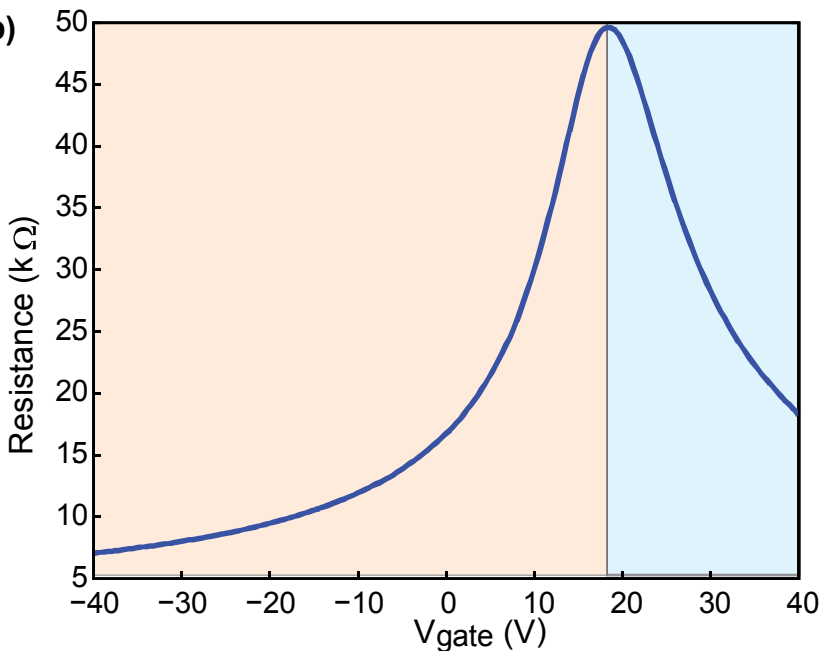

SI Figure 1. a, Optical contrast map of a single layer of graphene on top of a $\operatorname{SiN}_{\mathrm{x}}(20 \mathrm{~nm})$ / $\mathrm{SiO}_{2}(x \mathrm{~nm})$ on $\mathrm{Si}$ substrate. Contrast is plotted as a function of wavelength and $\mathrm{SiO}_{2}$ thickness. Optimal visibility of graphene is achieved with a $60 \mathrm{~nm}$ thick $\mathrm{SiO}_{2}$ layer. b, Room-temperature resistance (blue) versus back-gate voltage of a CVD grown graphene nanoribbon on a $270 \mathrm{~nm}$ thick $\mathrm{SiO}_{2}$ on $\mathrm{Si}$ substrate. P-type regime is indicated in pink and n-type in blue. 

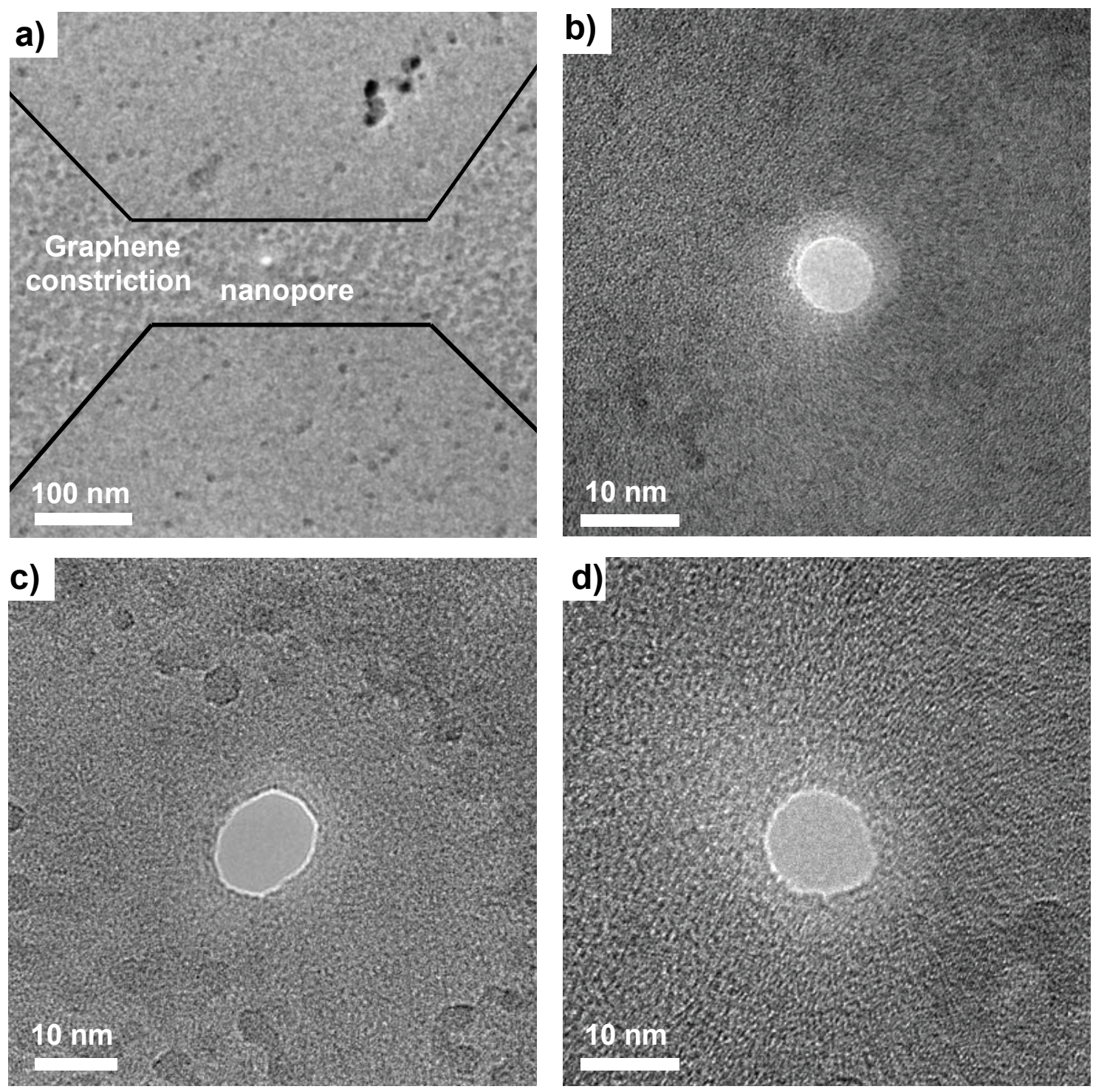

SI Figure 2. TEM micrographs of the pores used in the experiments presented in the paper. a, TEM micrograph of a GNR with a drilled pore. $\mathbf{b}$ and $\mathbf{c}$, and $\mathbf{d}$ zoom-in TEM micrographs of drilled nanopores. 


\section{SI-FIGURE 3}
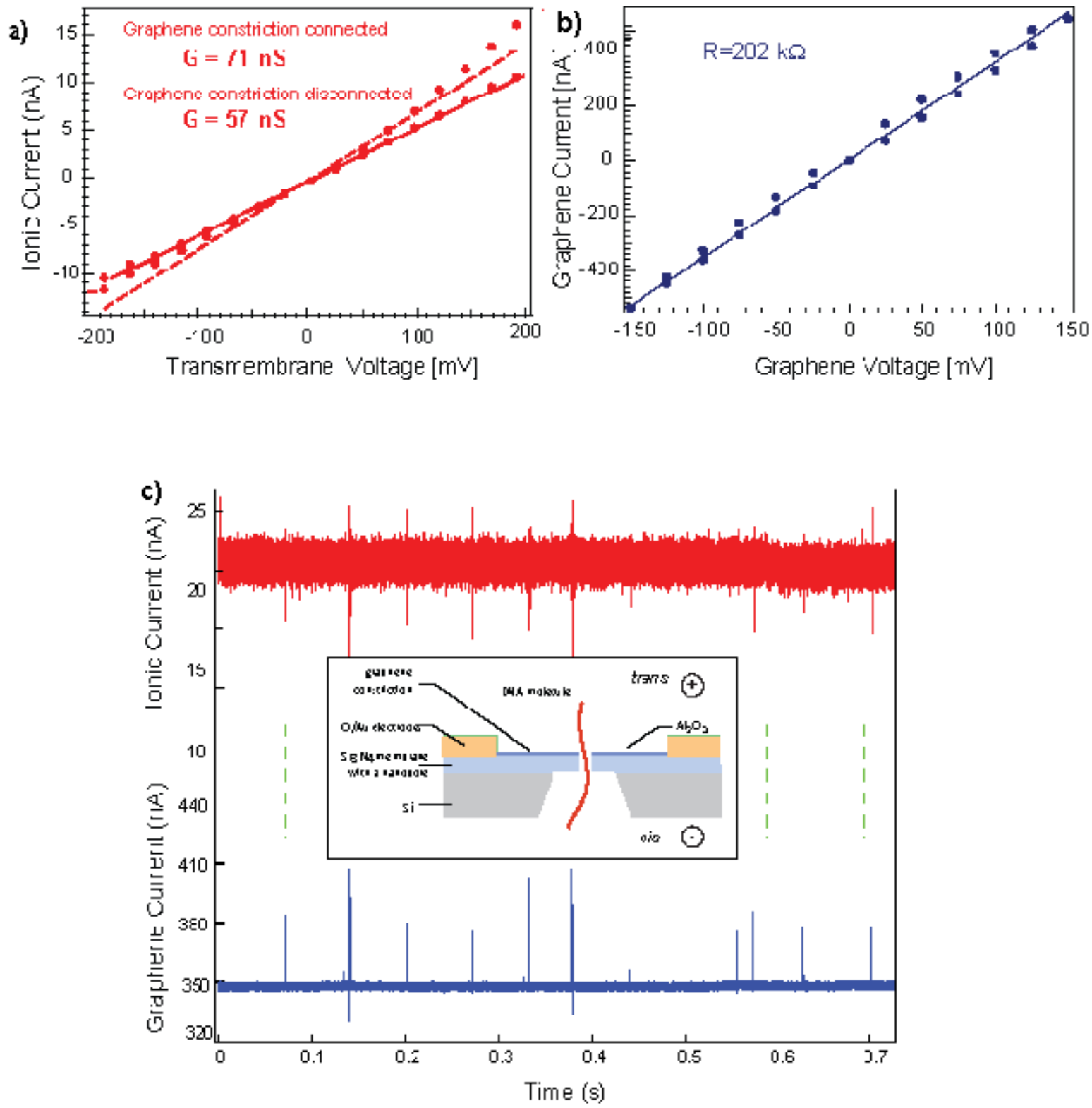

SI Figure 3. a, Pore $\mathrm{I}-\mathrm{V}$ characteristics of a nanopore in $1 \mathrm{M} \mathrm{KCl}$ buffer. The continuous line fits the measurement of the pore current with the GNR floating; the shaded line fits the measurement of the pore current with the GNR connected to the instrumentation. $\mathbf{b}, \mathrm{I}-\mathrm{V}$ characteristics of a GNR in $1 \mathrm{M} \mathrm{KCl}$ buffer (same device as in Fig. SI-3a); the continuous line fits experimental data of the graphene current. c, simultaneously recorded ionic current and graphene current during the 
translocations of $\lambda$-DNA in $1 \mathrm{M} \mathrm{KCl}$ (same device as in Fig. SI-3a and Fig. SI-3b); transmembrane voltage is equal to $200 \mathrm{mV}$, graphene source-drain voltage is equal to $20 \mathrm{mV}$. Ionic current is displayed in red, graphene current is displayed in blue. Inset shows schematic drawing of our setup (side view). A single $\lambda$ DNA molecule is translocating through a nanopore fabricated in a $\operatorname{SiN}_{x}$ membrane. 


\section{SI-FIGURE 4}
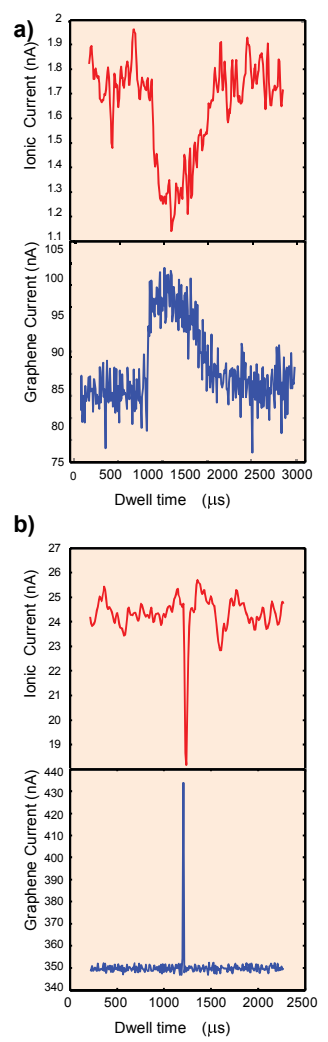

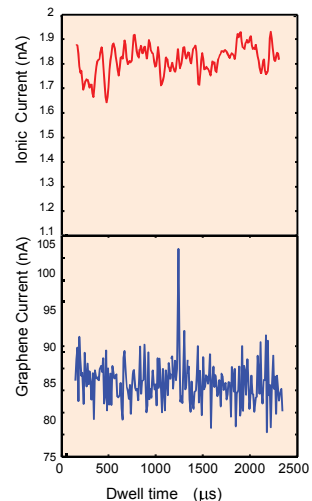

Dwell time $(\mu \mathrm{s})$

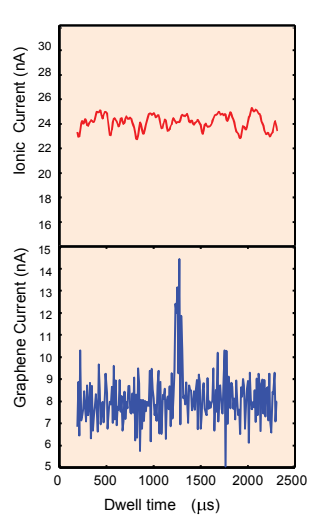

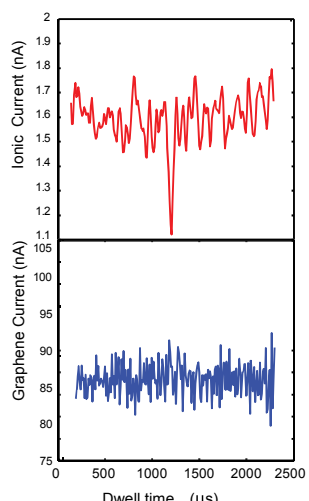

Dwell time $(\mu \mathrm{s})$

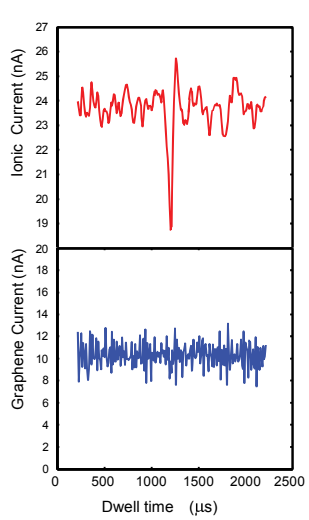

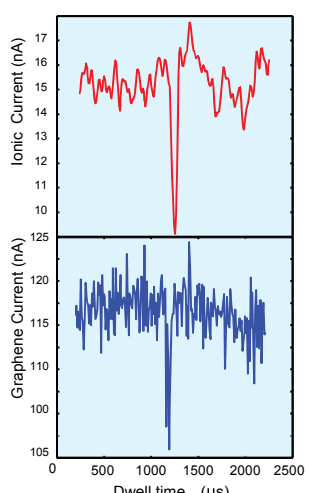

Dwell time $(\mu \mathrm{s})$

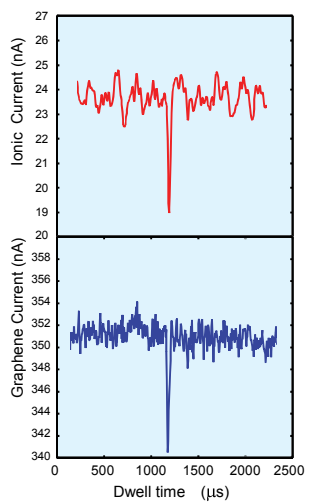

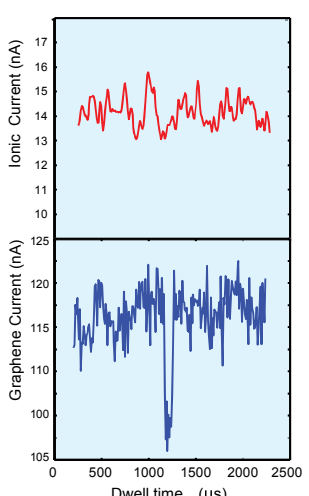

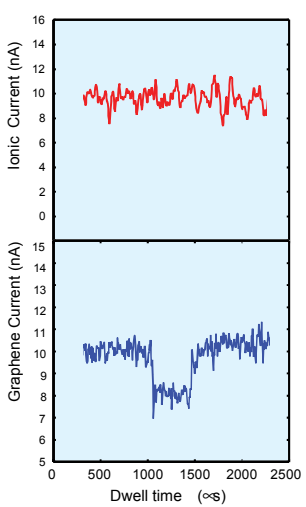

SI Figure 4. Zoom-in views of anomalous and typical events detected during translocation experiments in $10 \mathrm{mM} \mathrm{KCl}$ buffer solution $\mathbf{a}$. and $1 \mathrm{M} \mathrm{KCl}$ buffer solutions $\mathbf{b}$. Colour indicates p(pink) or n-type (blue) graphene transistor behaviour. 


\section{SI-FIGURE 5}
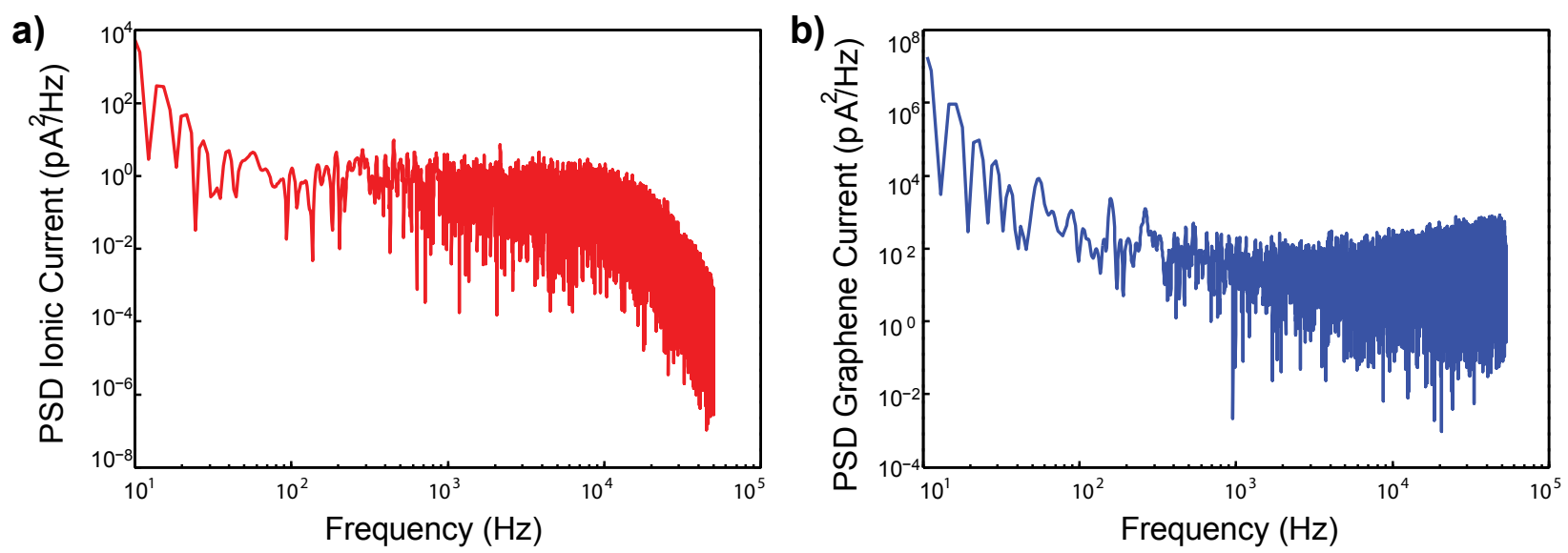

SI Figure 5. Power spectral density (PSD) graphs of the ionic current a. and the graphene current b . in a typical experiment in $10 \mathrm{mM}$ buffer solution. Transmembrane voltage applied is $200 \mathrm{mV}$, voltage applied across the GNR is $20 \mathrm{mV}$. A sample of signal without events was chosen for computing the PSD. 


\section{SI-FIGURE 6}

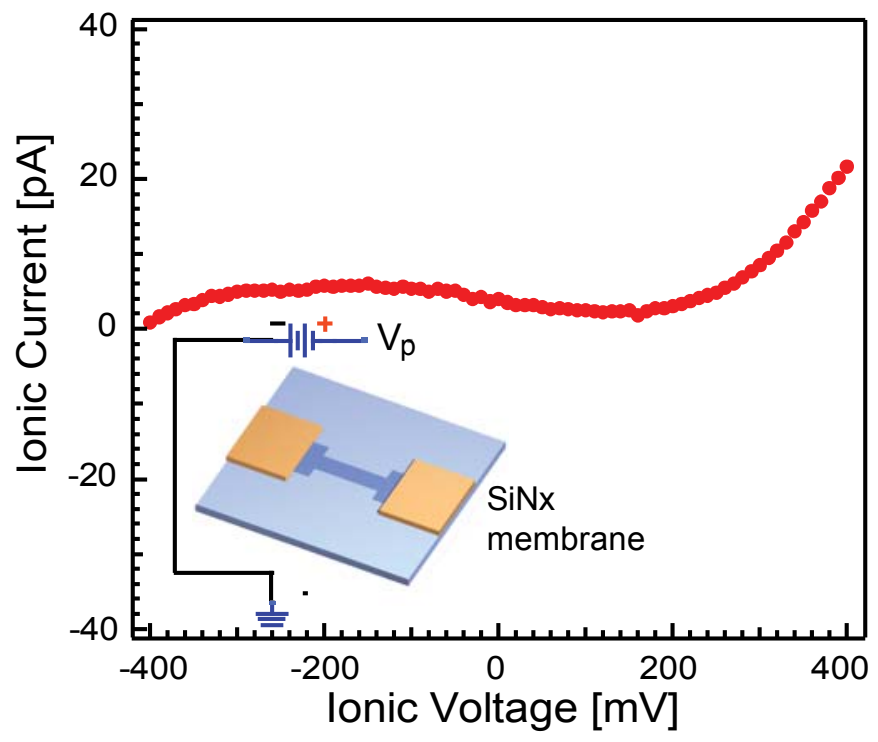

SI Figure 6. Ionic current voltage characteristics for the graphene nanorribon device without nanopore taken in $10 \mathrm{mM} \mathrm{KCl}$ buffer conditions. Very small current of $10 \mathrm{pA}$ proves minimal graphene electrochemical activity and excellent passivation via $\mathrm{Al}_{2} \mathrm{O}_{3}$. 


\section{SI-FIGURE 7}

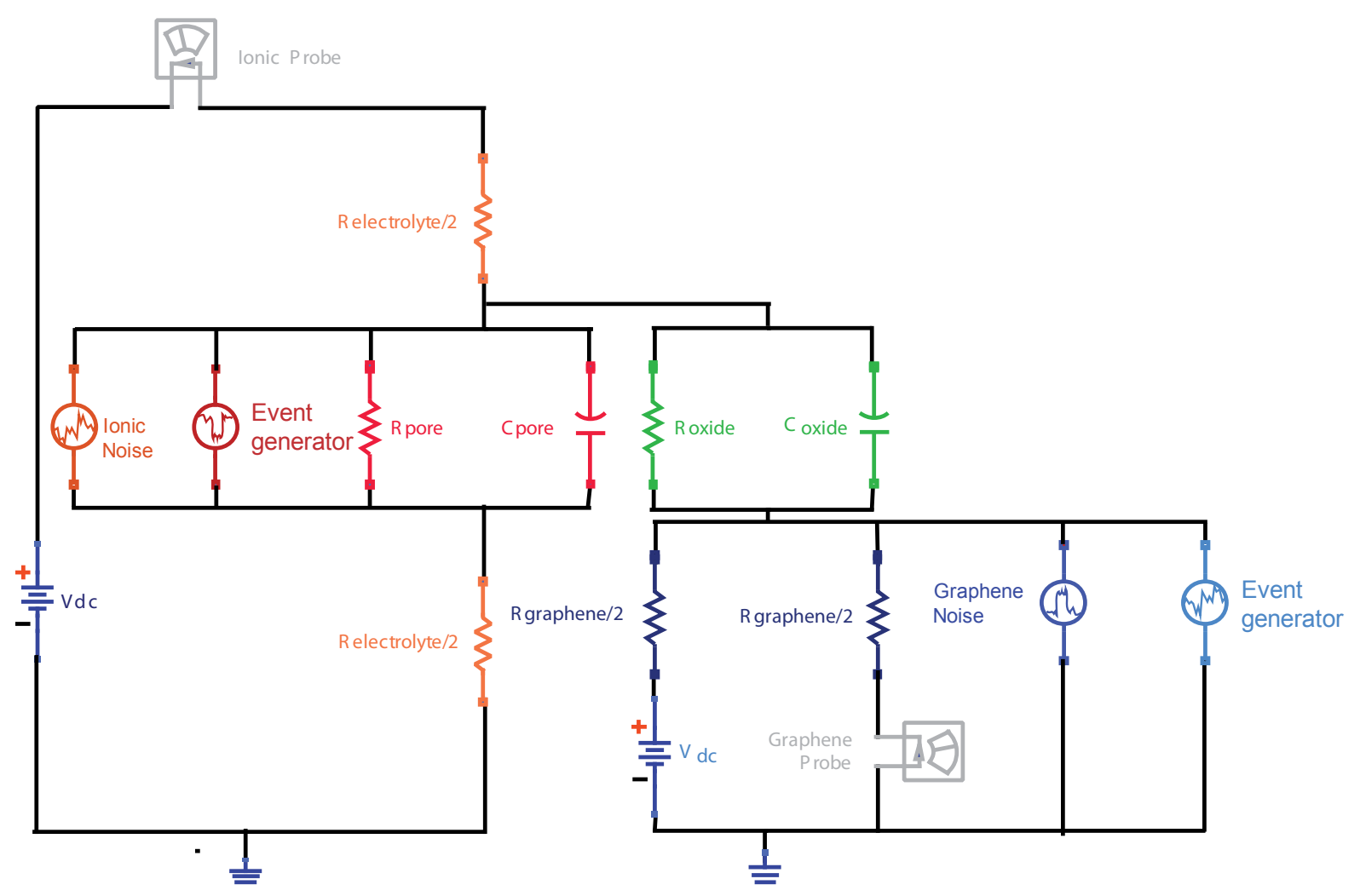

SI Figure 7. Schematics of the simplified lumped element model of our device used to analyse and test if the signal transmitted in the part of the circuit related to ionic current detection creates an undesired effect in the graphene circuit and vice versa. 


\section{SI-FIGURE 8}
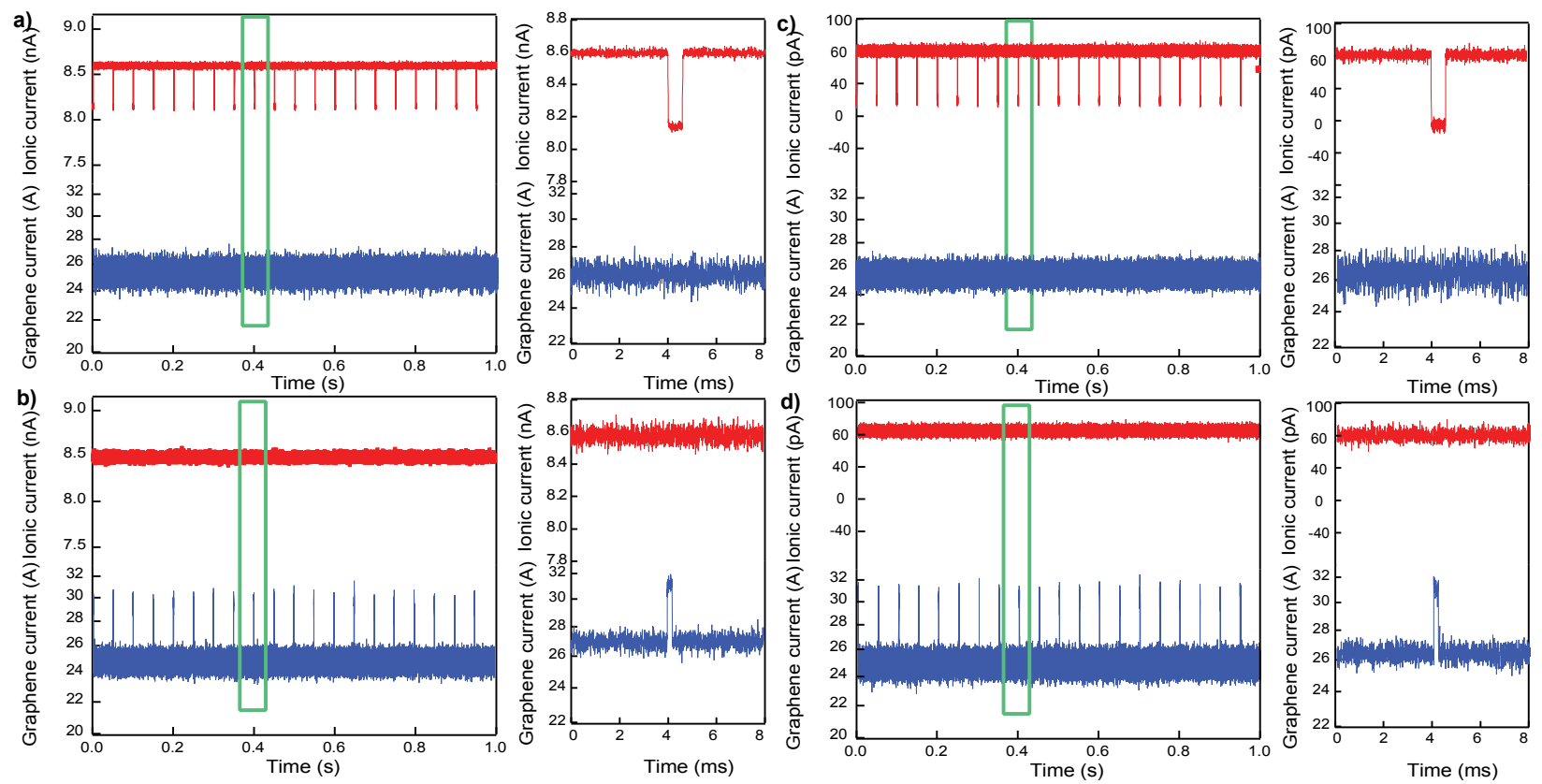

SI Figure 8. ADS simulated ionic and graphene nanorribon current at $500 \mathrm{mV}$ ionic bias and

$10 \mathrm{mV}$ graphene bias conditions in a) series of simulated ionic current drops are not transmitted to the graphene channel in $\mathbf{b}$ series of the events observed in graphene channel are not transmitted to the ionic channel. $\mathbf{a}$ and $\mathbf{b}$ display simulated currents at $1 \mathrm{M} \mathrm{KCl}$ while in $\mathbf{c}$ and $\mathbf{d}$ currents are simulated for $10 \mathrm{mM} \mathrm{KCl}$ buffer condition. 


\section{SI-FIGURE 9}

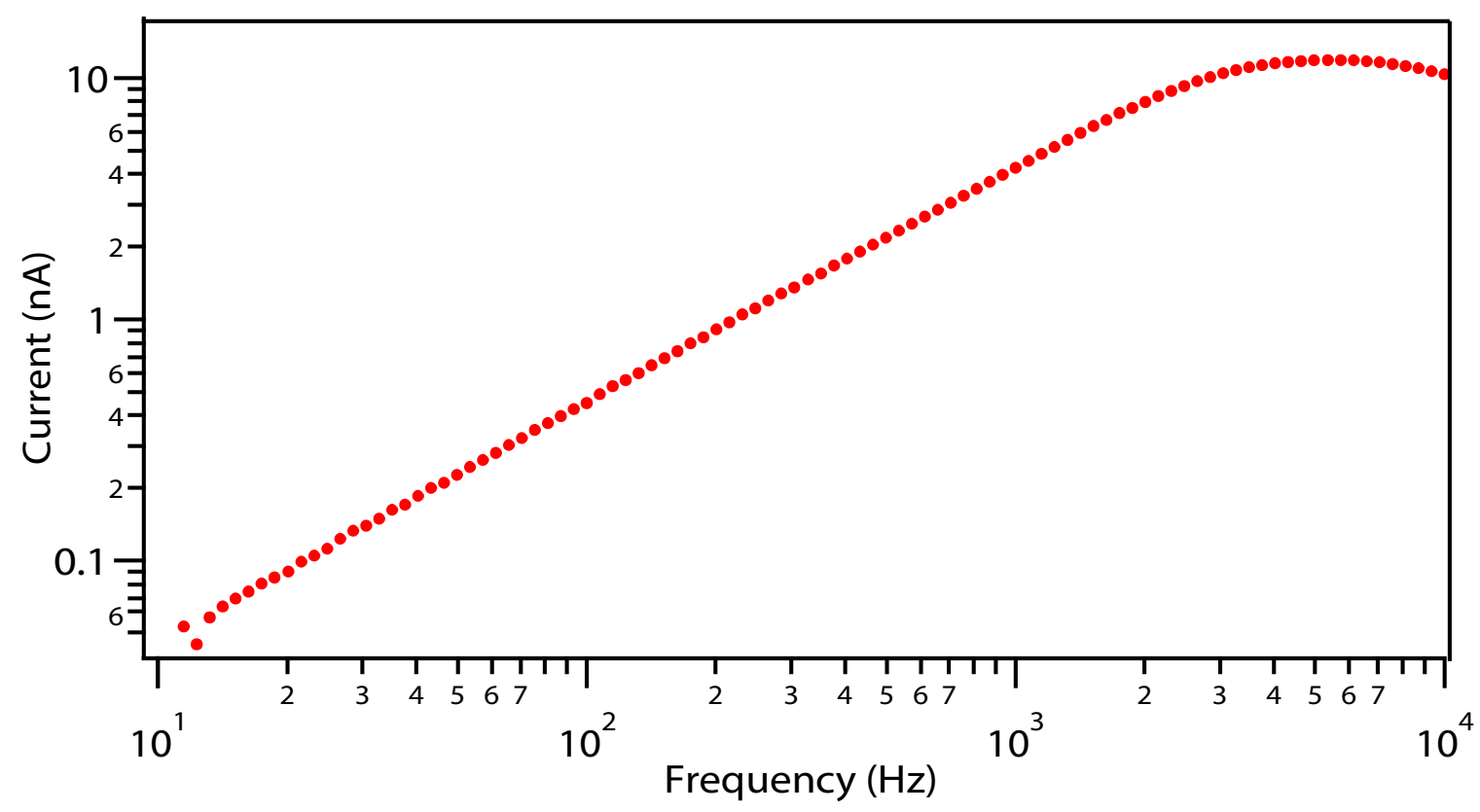

SI Figure 9. The pore current as a function of frequency measured in $1 \mathrm{M} \mathrm{KCl}$ through $20 \mathrm{~nm}$ thick silicon nitride with a $9 \times 8 \mathrm{~nm}$ nanopore. Nanopore is placed on the membrane $20 \mu \mathrm{m} \times 20$ $\mu \mathrm{m}$ large. Membrane and GNR device are fabricated as described in the methods section. At low frequency the pore resistance dominates and the current is independent of frequency. At higher frequency, on the other hand the membrane capacitance predominates, and the current increases with frequency as reported in ref 1. 


\section{SI-FIGURE 10}
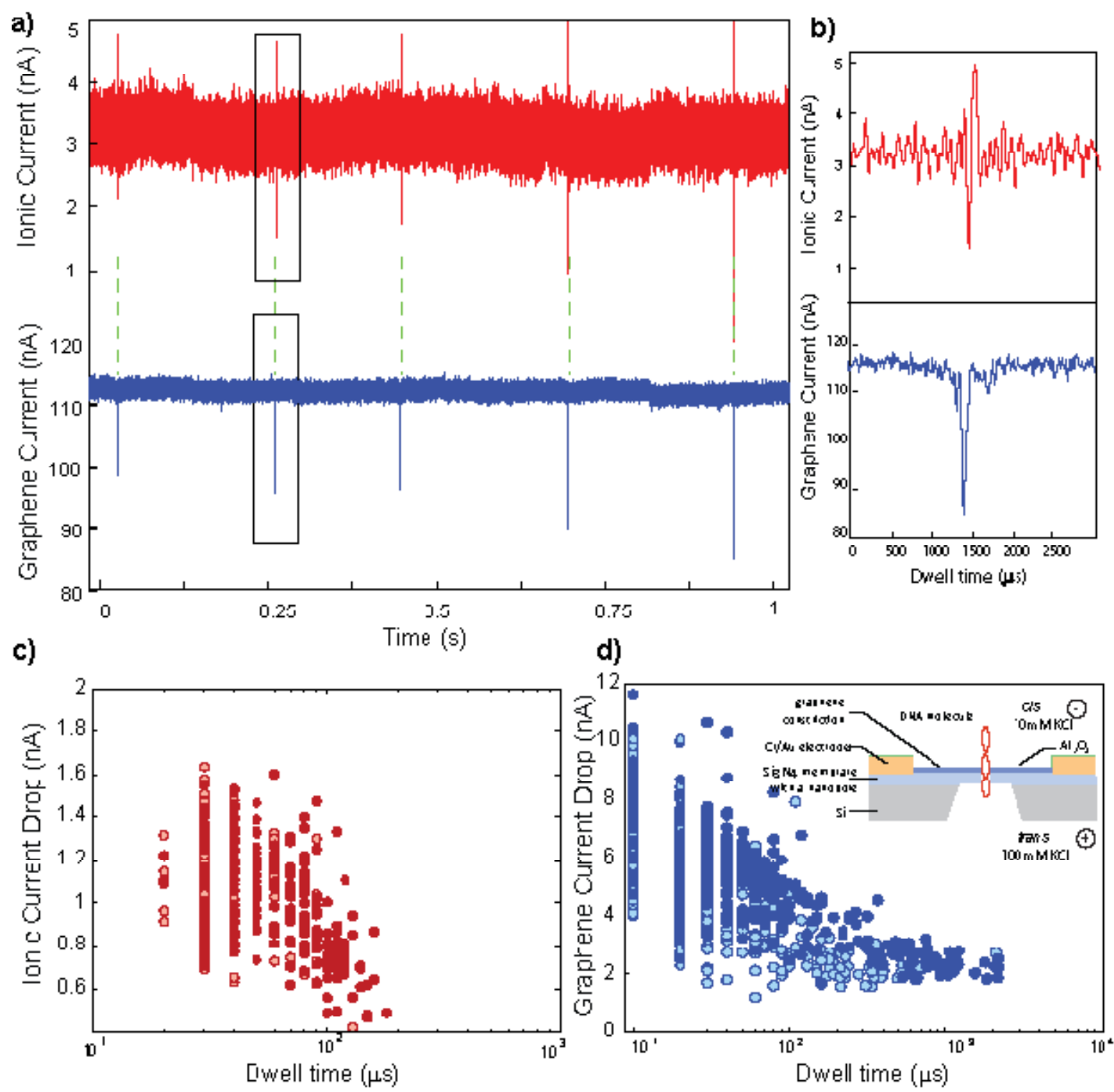

d)

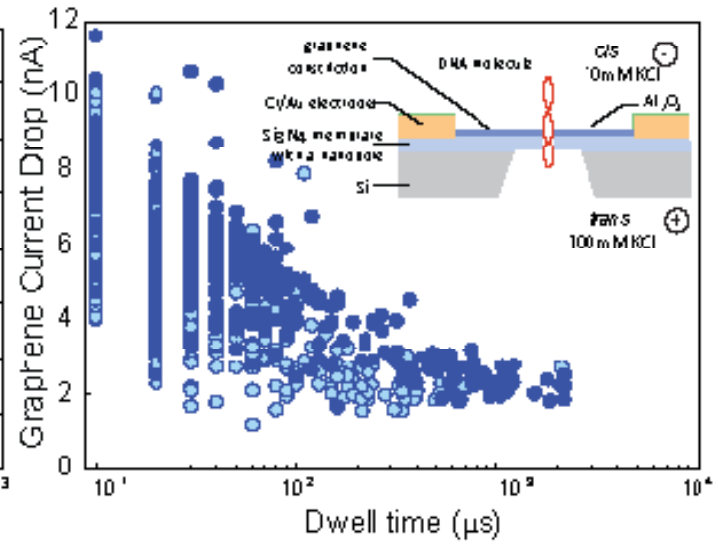

SI Figure 10. Simultaneous detection of DNA translocations in ionic and graphene current in salt gradient conditions. a, Simultaneously recorded ionic current and electrical current flowing through the graphene nanoribbon during the translocations of pNEB DNA in salt gradient conditions $(10 \mathrm{mM} \mathrm{KCl}$ in cis chamber $100 \mathrm{mM} \mathrm{KCl}$ in trans chamber) transmembrane voltage is equal to $400 \mathrm{mV}$, graphene source-drain voltage is equal to $20 \mathrm{mV}$. Ionic current is displayed in red, graphene current is displayed in blue. b, Zoom-in view of a single correlated event. c, Scatter plot of the events detected in the ionic current. d, Scatter plot of the events 
detected in the graphene current. Correlated events are represented by full coloured circles, uncorrelated events are represented by partially transparent circles. Inset shows schematic drawing of our setup (side view). A single pNEB 193 plasmid DNA molecule is translocating through a nanopore fabricated in a SiNx membrane, in this geometry graphene is placed in the cis chamber and measurements are obtained in salt gradient conditions. We observe 923 events in graphene channel (41\% correlated) with mean amplitude of $5 \mathrm{nA}$ and 532 events in ionic channel ( $71 \%$ correlated) having mean amplitude $1 \mathrm{nA}$. 


\section{SI FIGURE 11}

Concentration $1 \mathrm{M}$

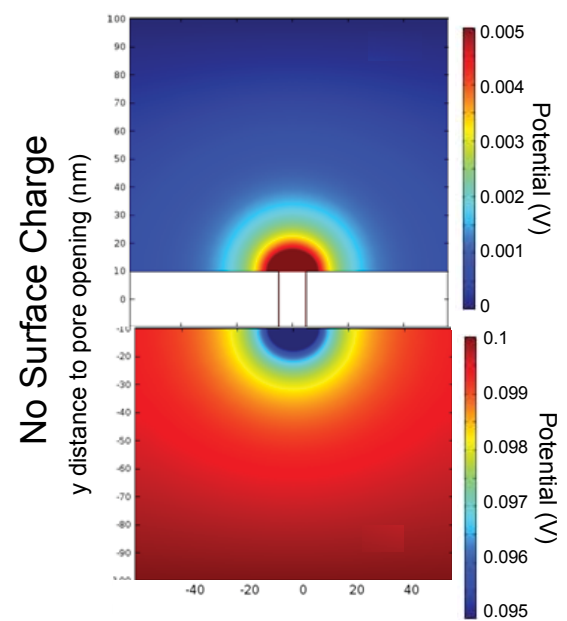

$\mathrm{x}$ distance to pore opening $(\mathrm{nm})$
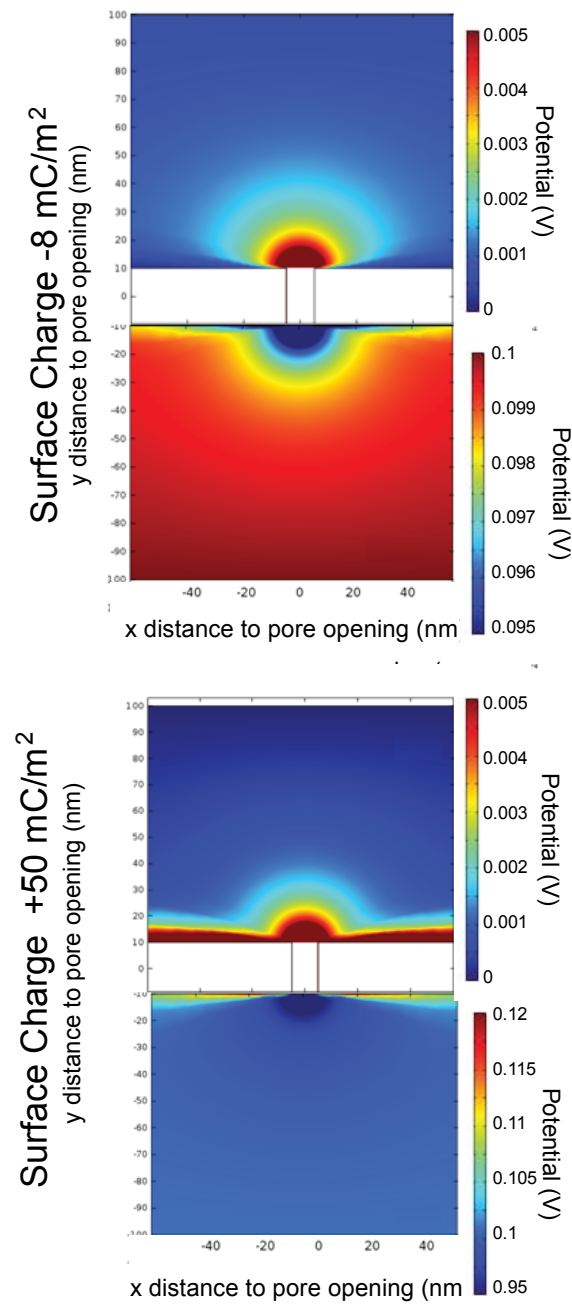

Concentration $10 \mathrm{mM}$

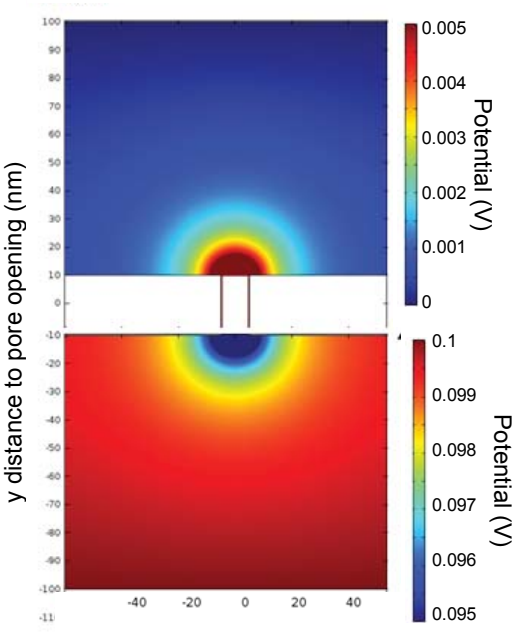

$\mathrm{x}$ distance to pore opening $(\mathrm{nm})$
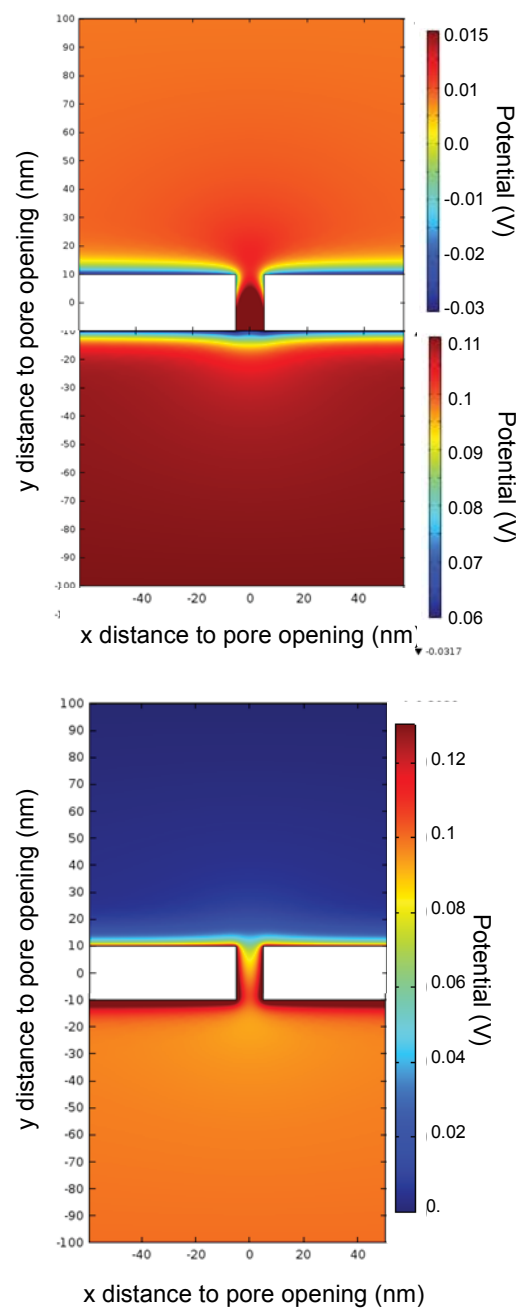

Concentration gradient $10 \mathrm{mM} / 100 \mathrm{mM}$

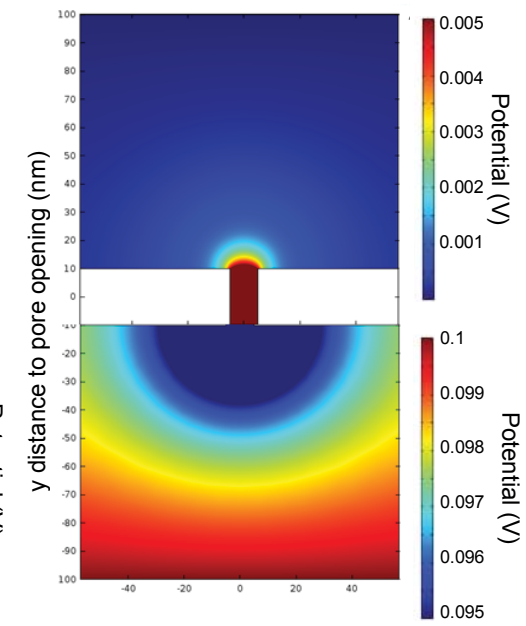

$\mathrm{x}$ distance to pore opening $(\mathrm{nm})$
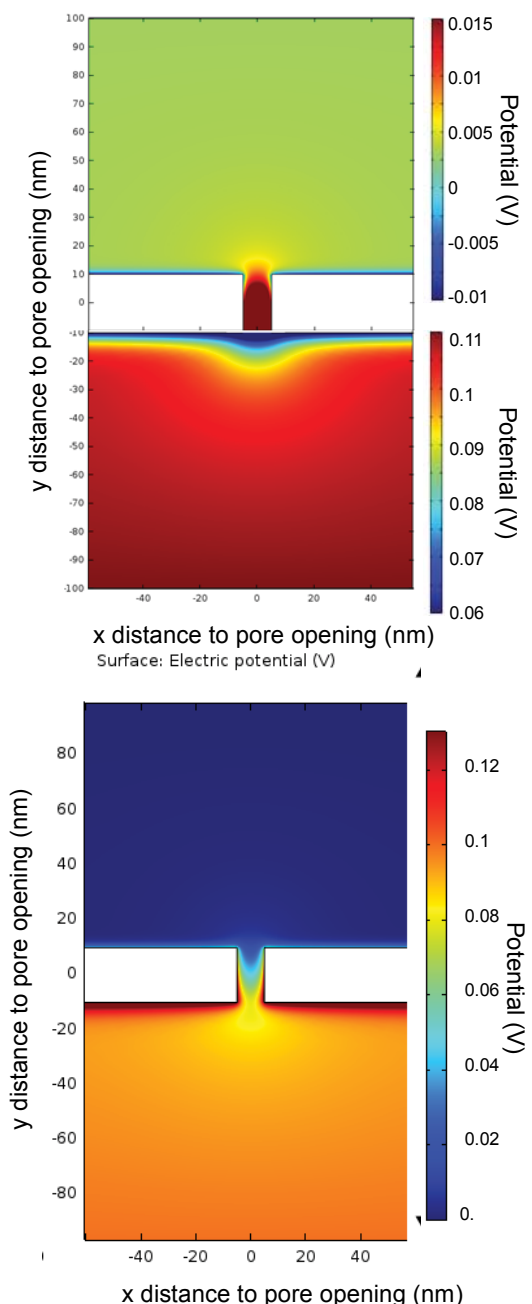
SI Figure 11. Simulations of the electric potential distribution of the nanopore in two dimensions. Simulations geometry is described in SI. Nanopore surface charges were set to no charge $1^{\text {st }}$ row , $-8 \mathrm{mC} / \mathrm{m}^{2}$ (associated with $\mathrm{SiN}_{\mathrm{x}}$ ) charge $2^{\text {nd }}$ row and $+50 \mathrm{mC} / \mathrm{m}^{2}$ (associated with $\left.\mathrm{Al}_{2} \mathrm{O}_{3}\right) 3^{\text {rd }}$ row. Simulations are performed at 3 ionic strength conditions $1 \mathrm{M} \mathrm{KCl}, 10 \mathrm{mM} \mathrm{KCl}$ and salt gradient condition $10 \mathrm{mM} \mathrm{KCl}$ cis and $100 \mathrm{mM}$ trans chamber for applied voltage of 100 $\mathrm{mV}$. Evidently presence of the surface charge influences the electric field potential distributions and can't be neglected. 


\section{SI Figure 12.}

a)

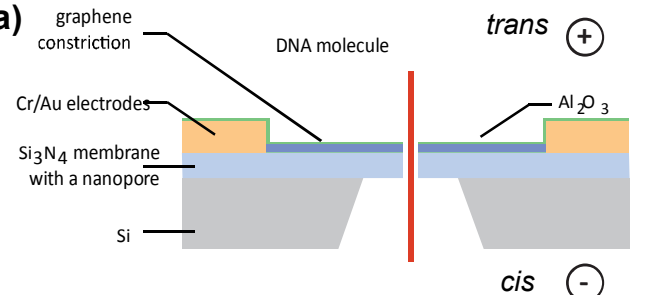

b)

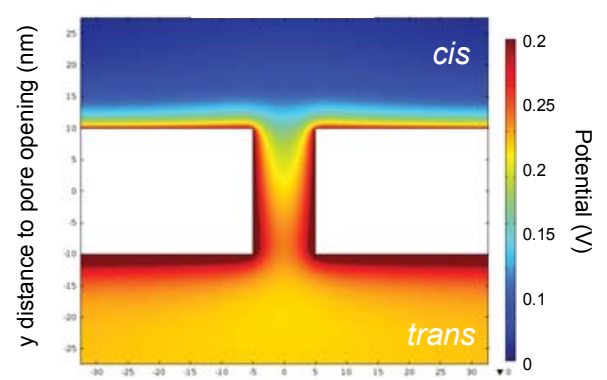

c)

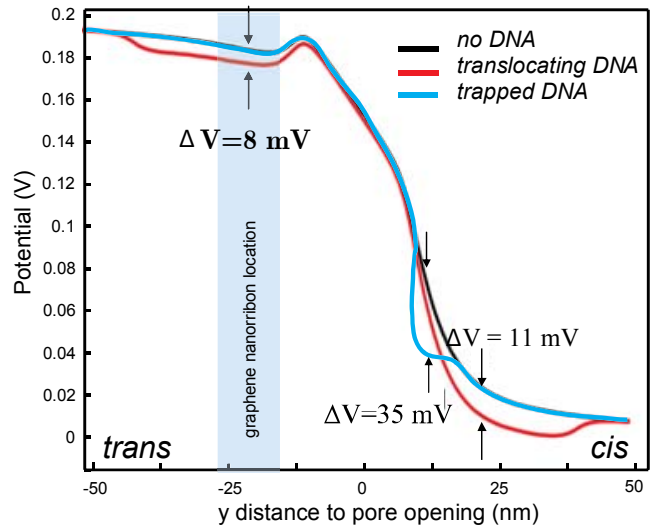

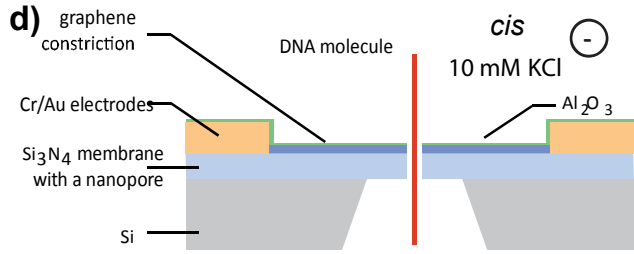

$100 \mathrm{mM} \mathrm{KCl}$ trans $\odot$

e)

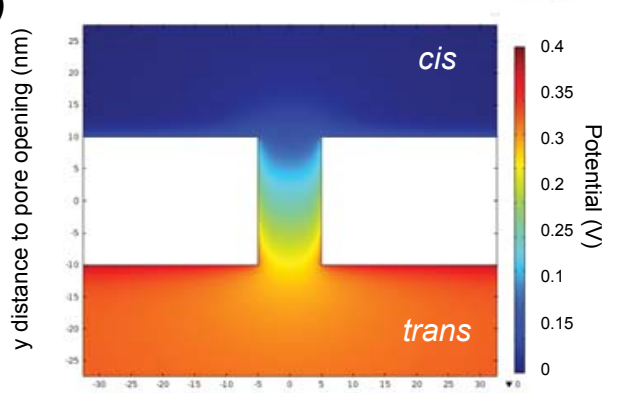

f)

$\mathrm{x}$ distance to pore opening $(\mathrm{nm})$

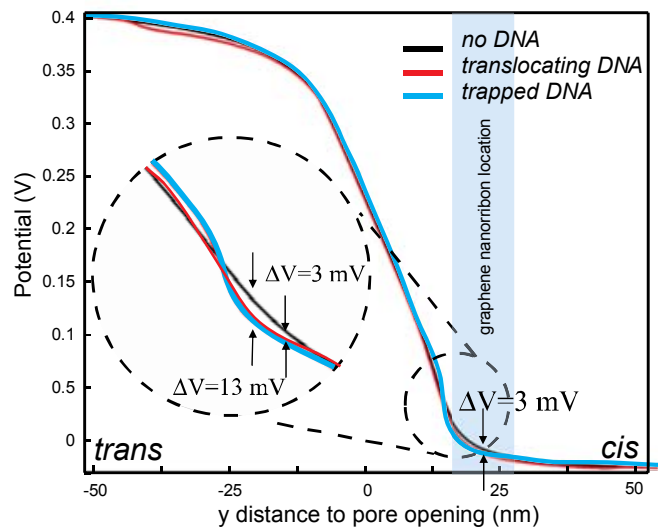

SI Figure 12. COMSOL simulations of the electric potential change due to the presence of DNA either in translocating or trapping configuration. Simulations are performed for the experimental conditions presented in Figure 3. schematics shown in a and SI Figure 10 schematics shown in $\mathrm{d}$, b A close up view of the electric potential distribution for the experimental conditions when applied field is $200 \mathrm{mV}(10 \mathrm{mM} \mathrm{KCl})$ while in e the applied voltage is set to $400(10 \mathrm{mM}$ cis $/ 100 \mathrm{mM}$ trans $)$ c potential change is monitored at the location of the graphene device i.e. trans side for $10 \mathrm{mM}$ ionic strength condition for three different 
conditions: pore without DNA, translocating DNA and trapped DNA. Here we consider y $<-10 \mathrm{~nm}$ — trans side, $-10 \mathrm{~nm}<\mathrm{y}<10 \mathrm{~nm}$ - nanopore, $\mathrm{y}>10 \mathrm{~nm}$ - cis side. Translocating dsDNA is modelled as extended $50 \mathrm{~nm}$ long linear segment, for plasmid we assume additive contributions of two dsDNA linear segments resulting in the potential changes of $\Delta \mathrm{V}=16 \mathrm{mV}$. Trapped dsDNA attenuates the potential for $\Delta \mathrm{V}=35 \mathrm{mV}$. $\mathbf{f}$ potential change is monitored at the location of the graphene device i.e. on cis side for gradient conditions $10 \mathrm{mM}$ ionic strength on chis side and $100 \mathrm{mM}$ at the trans (note this gradient is opposite to one used in Xie et al ${ }^{15}$ ) $400 \mathrm{mV}$ transmembrane bias for three different conditions: pore without DNA, translocating DNA and trapped DNA. Translocating dsDNA is modelled as extended 50nm long linear segment, for plasmid we assume additive contributions of two dsDNA linear segments resulting in the potential changes of $\Delta \mathrm{V}=3 \mathrm{mV}$. Trapped dsDNA attenuates the potential for $\Delta \mathrm{V}=6 \mathrm{mV}$. 


\begin{tabular}{|l|l|l|l|}
\hline Parameter & $\begin{array}{l}10 \mathrm{mM} \text { KCl (ionic } \\
\text { strength) }\end{array}$ & $\begin{array}{l}1 \mathrm{M} \quad \mathrm{KCl} \text { (ionic } \\
\text { strength) }\end{array}$ \\
\hline Vp(Transmembrane Voltage) & $500 \mathrm{mV}$ & $500 \mathrm{mV}$ & \\
\hline Vg ( Graphene voltage) & $10 \mathrm{mV}$ & $10 \mathrm{mV}$ & \\
\hline Rpore & $750 \mathrm{M} \Omega$ & $50 \mathrm{M} \Omega$ \\
\hline Relectrolyte & $75 \mathrm{M} \Omega$ & $5 \mathrm{M} \Omega$ \\
\hline R graphene & $400 \mathrm{k} \Omega$ & $400 \mathrm{k} \Omega$ & \\
\hline R oxide & $10 \mathrm{G} \Omega$ & $10 \mathrm{G} \Omega$ & \\
\hline Cpore & $1.8 \mathrm{nF}$ & $4.16 \mathrm{nF}$ & \\
\hline Coxide & $0.2 \mathrm{pF}$ & $0.2 \mathrm{pF}$ & \\
\hline
\end{tabular}

Table 1. ADS model parameters for two ionic strength conditions used in the simulation performed on the circuit shown in SI Figure 6. 


\begin{tabular}{|c|c|c|c|c|c|c|}
\hline Pore dimensions & Gp (disconnected) & Gp (conn) & Rg before & $\begin{array}{l}\text { Rg after } \\
\text { drilling }\end{array}$ & $\begin{array}{c}\text { Constriction } \\
\text { width }\end{array}$ & \\
\hline $20 \mathrm{~nm} \times 15 \mathrm{~nm}$ & $57.4 \mathrm{nS}(1 \mathrm{M})$ & 70.9 nS (1 M) & $19 \mathrm{k}$ & $3.4 \mathrm{M}$ & $60 \mathrm{~nm}$ & $\begin{array}{l}\text { SI-Fig. } 3 \text { and SI- } \\
\text { Fig. } 4\end{array}$ \\
\hline $8 \mathrm{~nm} \times 9 \mathrm{~nm}$ & $5 \mathrm{nS}(1 \mathrm{M})$ & $4 \mathrm{nS}(1 \mathrm{M})$ & $13.5 \mathrm{k}$ & $270 k$ & $220 \mathrm{~nm}$ & Data not shown \\
\hline Info missing & 2.86 uS (1 M) & 2.89 uS (1 M) & $18 \mathrm{k}$ & $2.2 \mathrm{M}$ & $250 \mathrm{~nm}$ & Data not shown \\
\hline $8 \mathrm{~nm} \times 9 \mathrm{~nm}$ & $24.5 \mathrm{nS}(1 \mathrm{M})$ & $26.7 \mathrm{nS}(1 \mathrm{M})$ & $150 \mathrm{k}$ & $400 \mathrm{k}$ & $180 \mathrm{~nm}$ & SI Figure $4 \mathrm{t}$ \\
\hline $10 \mathrm{~nm} \times 10 \mathrm{~nm}$ & $7.97 \mathrm{nS}(1 \mathrm{M})$ & $8.76 \mathrm{nS}(1 \mathrm{M})$ & $80 \mathrm{k}$ & $150 \mathrm{k}$ & $150 \mathrm{~nm}$ & SI Figure4 \\
\hline Info missing & $2.87 \mathrm{nS}(10 \mathrm{mM})$ & $2.82 \mathrm{nS}(10 \mathrm{mM})$ & $55 \mathrm{k}$ & $260 k$ & $225 \mathrm{~nm}$ & Data not shown \\
\hline Info missing & $22.2 \mathrm{nS}(1 \mathrm{M})$ & $55.4 \mathrm{nS}(1 \mathrm{M})$ & $140 \mathrm{k}$ & $85 \mathrm{k}$ & Info missing & Data not shown \\
\hline $14 \mathrm{~nm} \times 11 \mathrm{~nm}$ & $5.12 \mathrm{nS}(10 \mathrm{mM})$ & $17.3 \mathrm{nS}(10 \mathrm{mM})$ & $16 k$ & $400 \mathrm{k}$ & $200 \mathrm{~nm}$ & $\begin{array}{c}\text { Figure } 1,34 \text {, and } \\
\text { SI Figure4 }\end{array}$ \\
\hline $7 \mathrm{~nm} \times 7 \mathrm{~nm}$ & $5.41 \mathrm{nS}$ (cis $1 \mathrm{M}$ - trans $10 \mathrm{mM}$ ) & $\begin{array}{c}5.97 \mathrm{nS} \text { (cis } 1 \mathrm{M} \text { - trans } 10 \\
\mathrm{mM} \text { ) }\end{array}$ & $75 k$ & $700 \mathrm{k}$ & $280 \mathrm{~nm}$ & Data not shown \\
\hline $18 \mathrm{~nm} \times 18 \mathrm{~nm}$ & $0.213 \mathrm{nS}(10 \mathrm{mM})$ & $0.226 \mathrm{nS}(10 \mathrm{mM})$ & $26 \mathrm{k}$ & $180 \mathrm{k}$ & $200 \mathrm{~nm}$ & Data not shown \\
\hline $10 \mathrm{~nm} \times 10 \mathrm{~nm}$ & $6.45 \mathrm{nS}(10 \mathrm{mM})$ & $7.01 \mathrm{nS}(10 \mathrm{mM})$ & $18 \mathrm{k}$ & $700 \mathrm{k}$ & $140 \mathrm{~nm}$ & Data not shown \\
\hline $7.5 \mathrm{~nm} \times 9.5 \mathrm{~nm}$ & $1.11 \mathrm{nS}(10 \mathrm{mM})$ & $1.15 \mathrm{nS}(10 \mathrm{mM})$ & $20 \mathrm{k}$ & $4.5 \mathrm{M}$ & $160 \mathrm{~nm}$ & SI Fig4 \\
\hline $16 \mathrm{~nm} \times 18 \mathrm{~nm}$ & $23.2 \mathrm{nS}(1 \mathrm{M})$ & $26.2 \mathrm{nS}(1 \mathrm{M})$ & $11 \mathrm{k}$ & $455 \mathrm{k}$ & $140 \mathrm{~nm}$ & Data not shown \\
\hline $11 \mathrm{~nm} \times 11 \mathrm{~nm}$ & $26 \mathrm{nS}(1 \mathrm{M})$ & $32 \mathrm{nS}(1 \mathrm{M})$ & $21 k$ & $500 k$ & $110 \mathrm{~nm}$ & Data not shown \\
\hline $8 \mathrm{~nm} \times 8 \mathrm{~nm}$ & $1.37 \mathrm{nS}(10 \mathrm{mM})$ & $1.16 \mathrm{nS}(10 \mathrm{mM})$ & $10 k$ & $310 \mathrm{k}$ & $170 \mathrm{~nm}$ & Data not shown \\
\hline $4.5 \mathrm{~nm} \times 6 \mathrm{~nm}$ & $1.18 \mathrm{nS}(10 \mathrm{mM})$ & $1.26 \mathrm{nS}(10 \mathrm{mM})$ & $9 k$ & $788 k$ & $300 \mathrm{~nm}$ & Data not shown \\
\hline $8 \mathrm{~nm} \times 9.5 \mathrm{~nm}$ & $1.33 \mathrm{nS}(10 \mathrm{mM})$ & $1.33 \mathrm{nS}(10 \mathrm{mM})$ & $7 k$ & $180 \mathrm{k}$ & $250 \mathrm{~nm}$ & Data not shown \\
\hline $6 \mathrm{~nm} \times 6 \mathrm{~nm}$ & $400 \mathrm{nS}(10 \mathrm{mM})$ & $400 \mathrm{nS}(10 \mathrm{mM})$ & $11 \mathrm{k}$ & $240 \mathrm{k}$ & $280 \mathrm{~nm}$ & Data not shown \\
\hline $15 \mathrm{~nm} \times 15 \mathrm{~nm}$ & $12.6 \mathrm{nS}(1 \mathrm{M})$ & 19.6 nS (1 M) & $70 \mathrm{k}$ & $2.6 \mathrm{M}$ & $40 \mathrm{~nm}$ & Data not shown \\
\hline $8 \mathrm{~nm} \times 8 \mathrm{~nm}$ & $3.32 \mathrm{nS}(1 \mathrm{M})$ & $47.6 \mathrm{nS}(1 \mathrm{M})$ & $18 \mathrm{k}$ & $230 \mathrm{k}$ & $450 \mathrm{~nm}$ & Data not shown \\
\hline $16 \mathrm{~nm} \times 9 \mathrm{~nm}$ & $1.28 \mathrm{nS}(10 \mathrm{mM})$ & $1.26 \mathrm{nS}(10 \mathrm{mM})$ & $9 \mathrm{k}$ & $85 k$ & $400 \mathrm{~nm}$ & Data not shown \\
\hline $7.5 \mathrm{~nm} \times 7.5 \mathrm{~nm}$ & $\begin{array}{r}9 \mathrm{nS} \text { (10mM@cis+graphene } \\
\text { and } 100 \text { mM@trans) }\end{array}$ & $\begin{array}{c}2.8 \mathrm{nS} \\
\text { (10mM@cis+graphene } \\
\text { and } 100 \mathrm{mM} @ \text { trans) }\end{array}$ & $10.5 \mathrm{k}$ & $130 k$ & $350 \mathrm{~nm}$ & SI Figure 10 \\
\hline
\end{tabular}

Table 2. Properties of working devices. 
